7. Reprod. Fert. (1966) 12, 399-403

BRIEF COMMUNICATION

\title{
FACTORS IN PREGNANCY BLOCKING: AGE AND REPRODUCTIVE BACKGROUND OF FEMALES: NUMBERS OF STRANGE MALES
}

\author{
R. K. CHIPMAN AND K. A. FOX \\ Department of Zoology, University of Vermont, \\ Burlington, Vermont 05401, U.S.A.
}

(Received 28th May 1966)

\begin{abstract}
Summary. Pregnancy blocking experiments involving 731 female laboratory mice (control and experimental) indicate: (1) an increased resistance among older females; (2) an equal susceptibility among parous and non-parous females; and (3) a lower pregnancy rate among females exposed to six males than those exposed to one or three males.
\end{abstract}

An exteroceptive block to pregnancy in the laboratory mouse has been described by Bruce $(1959,1960)$ wherein recently inseminated mice returned to oestrus when placed in a cage with a strange male or males. In these studies parous females were thought to be less readily blocked than non-parous females when placed individually in contact with a strange male, although this difference was not apparent when the females were caged inside the male stock box (and thus exposed to more than one male). The latter situation was considered to supply a stronger stimulus. In a subsequent study (Bruce, 1963), however, increasing the number of males to which a female was simultaneously exposed did not increase the incidence of pregnancy blocking, although the question of parous versus non-parous mice was not investigated. Most investigations on pregnancy blocking have involved young virgin mice. Parous mice may be assumed to be older than such females. Thus the apparent resistance of parous females could be due to age. The initial purpose of the present study was to investigate the effects of both age and parity on pregnancy blocking in laboratory mice. During the course of this investigation certain observations suggested that the incidence of pregnancy blocking could be enhanced by increasing the number of males to which individual females were exposed without contact. This effect was investigated further.

Swiss strain females from an outbred colony maintained in this laboratory were used in all experiments. Wild males previously shown to be capable of inducing pregnancy blocking served as strange males. Standard laboratory maintenance procedures and cages were employed throughout except for the special test cage (described below) used in Experiment 2. Females were housed 
six or more per stock cage before individual pairing with a vigorous, experienced stud male (Swiss) of proven fertility. After insemination (determined by the presence of the vaginal plug) the male was removed. All treatments began $24 \mathrm{hr}$ later. Pregnancy was determined by examination of the uteri at autopsy 7 days after insemination. Results were compared by $\chi^{2}$ analysis. In Experiment 1 , inseminated females were individually placed in a cage containing: (a) one resident wild strange male, or (b) two such males in separate compartments. In the latter exposure, direct contact was prohibited between any of the mice.

TABLE 1

PREGNANCY RATES (PER CENT) OF ISOLATED AND MALE-EXPOSED VIRGIN AND PAROUS FEMALES OF VARIOUS AGES; STATISTICAL COMPARISONS ARE MADE TO ISOLATED FEMALES OF THE SAME AGE AND REPRODUCTIVE BACKGROUND (SAMPLE SIZE IS GIVEN IN PARENTHESES)

\begin{tabular}{|c|c|c|c|c|c|c|c|c|c|}
\hline \multirow{2}{*}{$\begin{array}{c}\text { Age } \\
\text { (months) }\end{array}$} & \multirow{2}{*}{$\begin{array}{l}\text { Reproductive } \\
\text { condition }\end{array}$} & \multirow{2}{*}{$\begin{array}{l}\text { Isolated } \\
\% \text { pregnant }\end{array}$} & \multirow{2}{*}{$(n)$} & \multicolumn{6}{|c|}{ Exposed to: } \\
\hline & & & & $\begin{array}{l}\text { One ma } \\
\% \text { pregnant }\end{array}$ & $\stackrel{(\text { conta }}{(n)}$ & $P$ & $\begin{array}{l}\text { Two male } \\
\text { \% pregnant }\end{array}$ & $\begin{array}{r}\text { es (no } \\
(n)\end{array}$ & $\begin{array}{l}\text { ontact) } \\
P\end{array}$ \\
\hline $\begin{array}{l}2 \\
3 \\
3 \\
6 \\
6\end{array}$ & $\begin{array}{l}\text { Virgin } \\
\text { Virgin } \\
\text { Parous } \\
\text { Virgin } \\
\text { Parous }\end{array}$ & $\begin{array}{l}90 \\
88 \\
97 \\
94 \\
87\end{array}$ & $\begin{array}{l}(50) \\
(50) \\
(33) \\
(33) \\
(32)\end{array}$ & $\begin{array}{l}44 \\
53 \\
61 \\
70 \\
64\end{array}$ & $\begin{array}{l}(50) \\
(85) \\
(33) \\
(33) \\
(33)\end{array}$ & $\begin{array}{l}<0.001 \\
<0.001 \\
<0.001 \\
<0.05 \\
<0.05\end{array}$ & $\begin{array}{c}28 \\
- \\
- \\
56 \\
-\end{array}$ & $\begin{array}{l}(25) \\
(34)\end{array}$ & $\begin{array}{l}<0.001 \\
<0.001\end{array}$ \\
\hline
\end{tabular}

The exposure cage in Experiment 2 consisted of two levels. The lower section was formed of six parallel runways (each $2 \frac{1}{2} \times 2 \frac{1}{2} \times 24$ in. long) separated by solid partitions. A solid bottom held bedding and food. The upper section also consisted of six runways (each $2 \frac{1}{2} \times 2 \frac{1}{2} \times 28 \mathrm{in}$. long) with solid partitions, but had $\mathrm{a} \frac{1}{3}$ in. mesh wire top and bottom. This section covered the lower one (thus forming its top) with the runways of the two sections at right angles to one another. Each upper runway had a nest box at one end and a food container at the other, forcing the mouse to traverse the runways below. A variable number of wild males individually caged in the upper runways would thus soil portions of each lower runway. (Dominic (1964) has shown pregnancy block to result from exposure to male urine.) Six newly inseminated females were placed in individual bottom runways soiled by a total of one, three or six strange males present in the top section. Control females were placed in unsoiled runways with males absent. Females were also placed in the unsoiled upper runways with the bottom runways empty or containing six wild males. Physical contact between males or between females was not possible. An individual male and female could make only limited contact through the screened area $\left(2 \frac{1}{2} \times 22\right.$ in.) at the intersection of their runways.

The results of Experiment 1 are summarized in Table 1. The pregnancy rates for all groups of exposed females show significant reductions from the rates for groups of non-exposed females of the same ages and reproductive backgrounds. Parous and virgin females of the two ages examined ( 3 and 6 months) appear to be equally susceptible to pregnancy blocking. Six-month-old females 
are significantly more resistant to pregnancy blocking than 2-month-old females $(P<0.02)$ and 3-month-old females $(P<0.05$; data of virgin and parous combined). Although the exposed 3-month-old females have a higher pregnancy rate than those 2 months of age, the difference is not significant. The pregnancy rates of females exposed to two males simultaneously, but without contact, are lower than those of females exposed to one male. Although not considered statistically significant (at 2 months $0.05<P<0.10$; at 6 months $0 \cdot 10<P<0 \cdot 20$ ), the differences were of sufficient magnitude to warrant further investigation.

\section{TABLE 2}

PREGNANGY RATES OF 8-WEEK-OLD, VIRGIN, FEMALE WHITE MICE FOLLOWING EXPOSURE TO VARYING NUMBERS OF WILD STRANGE MALES IN A TWO-LEVEL RUNWAY SYSTEM (SAMPLE SIZE GIVEN IN PARENTHESES)

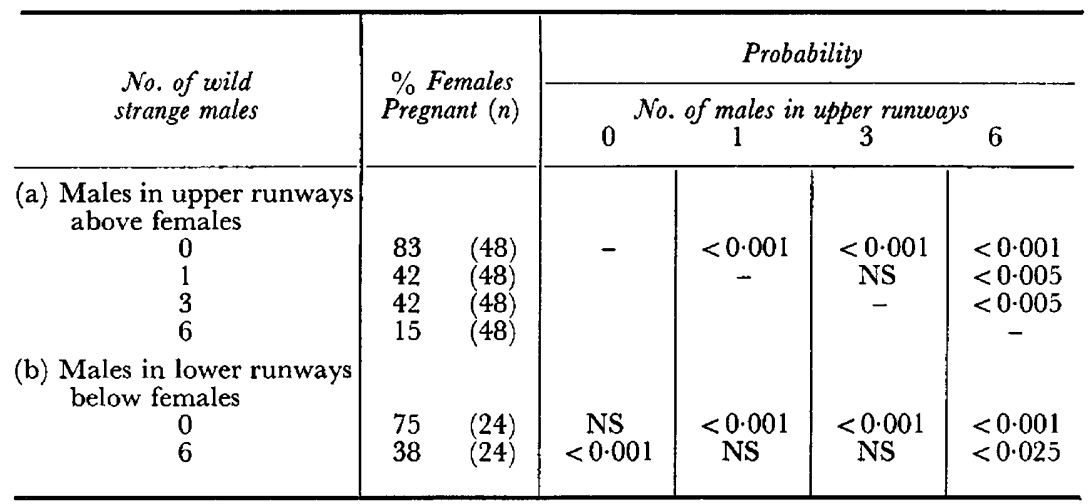

Results of Experiment 2 are given in Table 2. Females housed in lower runways soiled by one or more males show significantly reduced pregnancy rates. Exposure to six strange males produces significantly greater pregnancy blocking than exposure to one or three males. When females are housed in the upper runways with six males below, pregnancy failures occurred. However, blocking by six males in the lower runways is significantly less effective than blocking by six males in the upper runways.

Older females are clearly less susceptible to pregnancy blocking than younger ones. The explanation may lie in the degree of physiological maturity of the reproductive system (specifically the pituitary-ovarian axis). A 2-month-old female is reproductively active as indicated by a willingness to mate and a capacity to carry a litter to term (as is seen in non-exposed mice). Such females, however, have not reached the physical size and proportions of 6-month-old females. Mammalogists, recognizing that rodents become reproductively active intermediate between juvenile and adult stature, employ the term sub-adult for such animals. Thus our 2-month-old animals would be considered subadults. Bruce \& Parkes $(1960,1961)$ present evidence that pregnancy blocking results from insufficient luteotrophic activity. Presumably sub-adult females lack the neuroendocrinological stability found in adult females.

The reproductive background (parous versus non-parous) of females does 
not alter the susceptibility of newly inseminated females to pregnancy blocking when exposed by direct contact with the strange male. Bruce $(1959,1960)$ suggests that parous females are more resistant to blocking. However, parous females may be assumed older than the 'young virgin mice' and thus more resistant to blocking, as shown in the present study.

Under our experimental conditions of limited contact, an increase in the number of males to which a female is exposed increases the likelihood of pregnancy failure; exposure to six males produces significantly greater blocking than exposure to one or three males. This male-dose effect is also evident in the first experiment wherein exposure to two males produced greater blocking than exposure to one (Table 1). By increasing the number of males to which the female was exposed from one to eight, Bruce could not augment significantly the near-maximal response produced by one male. The pregnancy rate of females exposed to sixteen males, however, was considerably less than the rate of females exposed to one male. However, since the method of exposure in the present experiment (restricted contact) differs from that used by Bruce (1963) (direct contact), as did the strain of mice employed, close comparisons cannot be made.

The greater accumulation of excrement in the lower runways from six males may have provided sufficient annoyance to the female to decrease the pregnancy rate further. However, soiling was not excessive. Furthermore, in Experiment 1, where the female compartment was not soiled by the two strange males, there was still an increase $(0.05<P<0 \cdot 10)$ in pregnancy failures.

Recent investigations have shown that: (1) multiple short-term exposures are effective in producing pregnancy block (Chipman, Holt \& Fox, 1966), and (2) wild house mice are very susceptible to blocking (Chipman \& Fox, 1966). These studies suggest that pregnancy blocking may function in natural populations of house mice. As commensal house mice are known to use common trails (Young, Strecker \& Emlen, 1950; Brown, 1953) it is possible that periodic contacts between newly inseminated females and strange males or their odours may be adequate to induce pregnancy failure. The results of the present study show that investigations of pregnancy blocking in natural populations must necessarily consider the age of the reproductively active females and the density of males within the population. Such studies are now in progress.

This study was supported by a grant from the National Institutes of Health. The authors are indebted to Miss H. M. Bruce for her helpful suggestions on the manuscript.

\section{REFERENCES}

BRown, R. Z. (1963) Social behaviour, reproduction and population changes in the house mouse (Mus musculus L.). Ecol. Monogr. 23, 217.

Bruce, H. M. (1959) An exteroceptive block to pregnancy in the mouse. Nature, Lond. 184, 105.

BRUCE, H. M. (1960) A block to pregnancy in the mouse caused by proximity of strange males. $\mathcal{F}$. Reprod. Fert. 1, 96.

BRUCE, H. M. (1963) Olfactory block to pregnancy among grouped mice. F. Reprod. Fert. 6, 451.

Bruce, H. M. \& Parkes, A. S. (1960) Hormonal factors in exteroceptive block to pregnancy in mice. 7. Endocr. 20, xxix. 
Bruce, H. M. \& Parkes, A. S. (1961) The effect of concurrent lactation on the olfactory block to pregnancy in the mouse. F. Endocr. 22, vi.

ChIPman, R. K. \& Fox, K. A. (1966) Pregnancy failure in laboratory mice after multiple short-term exposure to strange males. F. Reprod. Fert. 12, 233.

Chirman, R. K., Holt, J. A. \& Fox, K. A. (1966) Pregnancy blocking after multiple, short-term exposure to strange males. Nature, Lond. 210, 653.

Domenc, C. J. (1964) Source of the male odour causing pregnancy block in mice. F. Reprod. Fert. 8, 266.

Young, H., Strecker, R. L. \& EMarn, J. T., JR. (1950) Localization of activity in two indoor populations of house mice, Mus musculus. 7. Mammal. 31, 403. 